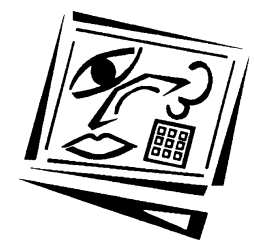

\title{
Web based projects enhancing English language and generic skills development for Asian hospitality industry students
}

\author{
Mei-jung Wang \\ National Kaohsiung Hospitality College
}

\begin{abstract}
This study investigated hospitality students' responses toward their learning experiences from undertaking group projects based upon a College web platform, the Ubiquitous Hospitality English Learning Platform (U-HELP). Twenty-six students in the Department of Applied Foreign Languages participated in this study. Their attitudes toward the process oriented activity conducted in the platform were investigated through questionnaires and final reports. The findings showed that the subjects held positive views towards web based learning and the interface design of the platform. Moreover, students' responses revealed that the web based projects had the following advantages: (1) enhancing cooperation, (2) improving hospitality knowledge, (3) promoting cognitive skills, and (4) raising computer literacy. However, negative comments were classified as follows: (1) the time consuming nature of group work, (2) preference for traditional paperwork, and (3) problems with using the platform. Based on the findings, some pedagogical suggestions for web based activities are presented.
\end{abstract}

\section{Background}

The unique attributes of networked multimedia environments, such as instant access to the abundant information on the Internet, the capabilities of synchronous and asynchronous communication, and the use of nonlinear forms of information presentation, make the Internet a strong candidate for use in language learning and acquisition (Chun \& Plass, 2000, El-Hindi, 1998; Herrington \& Standen, 2000; Jones, 2004; Lin, 2006). Therefore, web based learning is becoming increasingly utilised by educators as a supplement to traditional, face to face instruction. Moreover, Felix (2002) pointed out that what really matters in web based learning is the communication among users of the web. Similarly, Hoven (2006) indicated that a learning environment is the essentially intangible conflux of teachers, learners, physical resources (e.g. technology and library), soft technology (e.g. Internet facilities), and the network among all of these. Only when such a learning environment is established, can learning be fostered through exploration, communication, and collaboration. George, McCausland, Wache and Doskatsch, (2001) stressed that learners must develop skills to access information from appropriate sources, critically analyse and evaluate information, and then apply information for effective and creative decision making. Many universities worldwide have attempted to identify similar qualities they aim to inculcate in their graduates.

Along with the fact that e-learning is being increasingly integrated into higher education via a range of approaches, the demands of the contemporary work environment require employees to develop the skills to think creatively, solve 
problems and work effectively within a team. Additionally, in the hospitality industry, having respect for cultural traditions and being technologically astute are among the major competencies for management (Hse, 2008). Take Taiwan's hospitality culture for example. Taiwanese fine cuisine, night markets, annual events such as the Lantern Festival, the many aboriginal and Hakka festivals, as well as many other religious ceremonies and rituals, all combine to make Taiwan one of the most fascinating travel destinations in the world. However, the extent to which our students are familiar with our own hospitality culture and how well they can appropriately introduce Taiwan's hospitality culture to foreign guests is one issue. At the same time, our students' limited familiarity with foreign hospitality cultures is another area of concern.

To seek the answers to the aforementioned issues, a Ubiquitous Hospitality English Learning Platform (U-HELP) was implemented to supply web enhanced language learning resources and activities related to hospitality English. This study investigated students' responses toward the learning experiences of constructing English projects relevant to hospitality industry in the U-HELP. The projects students conducted in the U-HELP respond to specific needs of the students who will serve in the hospitality industry in the 21st century. Through the participation in the projects, students were exposed to situations they could relate to, and the situations promoted language use by giving students the opportunity to participate in tasks directly related to their future work duties and responsibilities. In addition, this study offered students the opportunity to cooperate with their peers and become more autonomous learners with key competencies to succeed in the digital age. Finally, this study might provide information about the potential of language acquisition for specific purposes through e-learning.

\section{Literature review}

Language instructional practices have been influenced by recent rapid and pervasive social and technological changes that have resulted in an increasing emphasis on the use of flexible methods of course delivery in higher education (Chen, 2003; Curtis \& Lawson, 2001; George, McCausland, Wache \& Doskatsch, 2001). Trends in language teaching today, such as process oriented composition, collaborative learning, and portfolio assessment, seem to dovetail with the current state of technology. Furthermore, technology enhanced learning has the potential to support innovation in instruction. Currently, those teachers who are conscious of information and communication technology (ICT) utilise web based programs to extend the curricula in powerful ways, enabling students to explore different points of view, to navigate at will non-linearly, and to process the information at their own pace (Marcum, 2002; Yi, 2001).

The learning theories supporting web based learning emphasise the creation of an environment where every learner can access a multitude of resources and pursue different areas in more depth. Most of the literature suggests that the principles underpinning social constructivism effectively support learning with ICT (Jonassen, Howland, Moore \& Marra, 2003; Maor, 2004). Social constructivism emphasises that knowledge exists in a social context and is shared with others, rather than represented solely in the mind of an individual. Moreover, higher psychological functions originate in interaction between individuals before they are transferred within the individual (Foster, 1998; Shen, 2006; Takahashi, 1998). When learners interact with one another, the process of sharing ideas provides them with opportunities to refine and reconstruct 
their internal thoughts. In this sense, web based learning is teacher orchestrated and student centered, with technology tools stimulating and supporting the learning process (Meskill \& Ranglova, 1999).

Similar to web based learning, project based learning (PBL) is a methodology that uses real world projects as the basis for teaching a variety of skills (Moss \& Van Duzer, 1998; Lawrence, 1997; Palincsar, 1991). In a project based learning course, teams of four to five students, under the supervision of an instructor, are responsible for producing projects from start to finish. Students must learn the skills of problem identification, planning, delegation among team members, time management, and interpersonal skills of communication and negotiation (Lawrence, 1997; Moss, 1998; Wrigley, 1998). Moreover, PBL is especially effective when supported by educational technology (Blumenfeld et al., 1991; Means \& Olson, 1997; Coley, Cradler \& Engel, 1997). Web based PBL teaches students vital "learning how to learn" skills as well as provides practice for the kinds of interaction needed in employment (Duch, 1996).

Turning to the issue of English instruction in hospitality education, Miller, Deutsche and Sealey-Ruiz (2004) stressed that hospitality education includes a socialisation process that exposes a myriad of cultures, philosophies, traditions, and interactions. Hse (2008) emphasised that hospitality education should provide students with opportunities to apply knowledge in practical settings. In addition, she pointed out that information technology, critical thinking, and problem solving skills are among the themes in current curricula. With the above characteristics considered, the instruction of English in hospitality education should be career oriented, focusing on language functions, such as requesting, refusing, suggesting, and confirming. As a result, students can be prepared to participate in the hospitality industry where learning to cooperate with others to reach mutual goals seems a necessary prerequisite for operating in a complex society.

In the past "general education" courses in Taiwan were intended to be "general English," and not English for specific purposes (ESP) in orientation. Currently, more and more research focuses on the design and implementation of ESP programs in order to equip our students with advanced language skills for career and academic development (Chang, 2009; Tsou, 2009). This seems to indicate that English language teachers and learners alike have perceived a need for a more well-developed grasp of English in terms of being better enabled to operate within the larger world of finance, commerce and industry. However, in an attempt to make the "general English" courses more ESP in orientation, there are a number of potential problems, including the shortage of qualified teachers and the limited number of hours of instruction. There is also the possibility of ESP courses being unduly limited to the learning of specific lexicon and the translation of content specific texts.

This project attempted to incorporate web based learning and PBL with English for hospitality purposes and investigate students' perceptions of the acquisition of foreign languages for specific purposes through e-learning. Three main research questions were addressed in this study:

1. What are students' responses to web based learning?

2. What are students' responses to the user interface design of the U-HELP?

3. What are students' responses to the process of hospitality project construction? 


\section{Methodology}

\section{Subjects}

The participants were twenty-six full time students in the Department of Applied Foreign Languages at a national college in Taiwan. They were first year students, aged from 19 to 20, in the 4-year college program on campus during the time of this study (September 2007 to January 2008). Some of the students worked part time in the hospitality industry before entering the college. Their English proficiency at the time was at about the TOEIC 500 level (which is about higher intermediate level of English proficiency). In addition, all of the students had taken computer courses in senior high school. For this study, students were self selected as pairs to conduct the online project.

\section{The questionnaire}

A questionnaire was designed to investigate the effectiveness of various attributes of the U-HELP. Items 1 to 7 are related to the instructional design of the platform and items 8 to 14 are concerned with the user interface design. Two professors, one from an English Department and the other from a Department of Educational Technology were invited to read the questionnaire. Both of them were satisfied with it and made some suggestions for the description of the items. The reliability of the questionnaire employed in the present study was 0.76 using Cronbach's alpha coefficient of internal consistency, a satisfactory level according to Nunnally and Bernstein (1994).

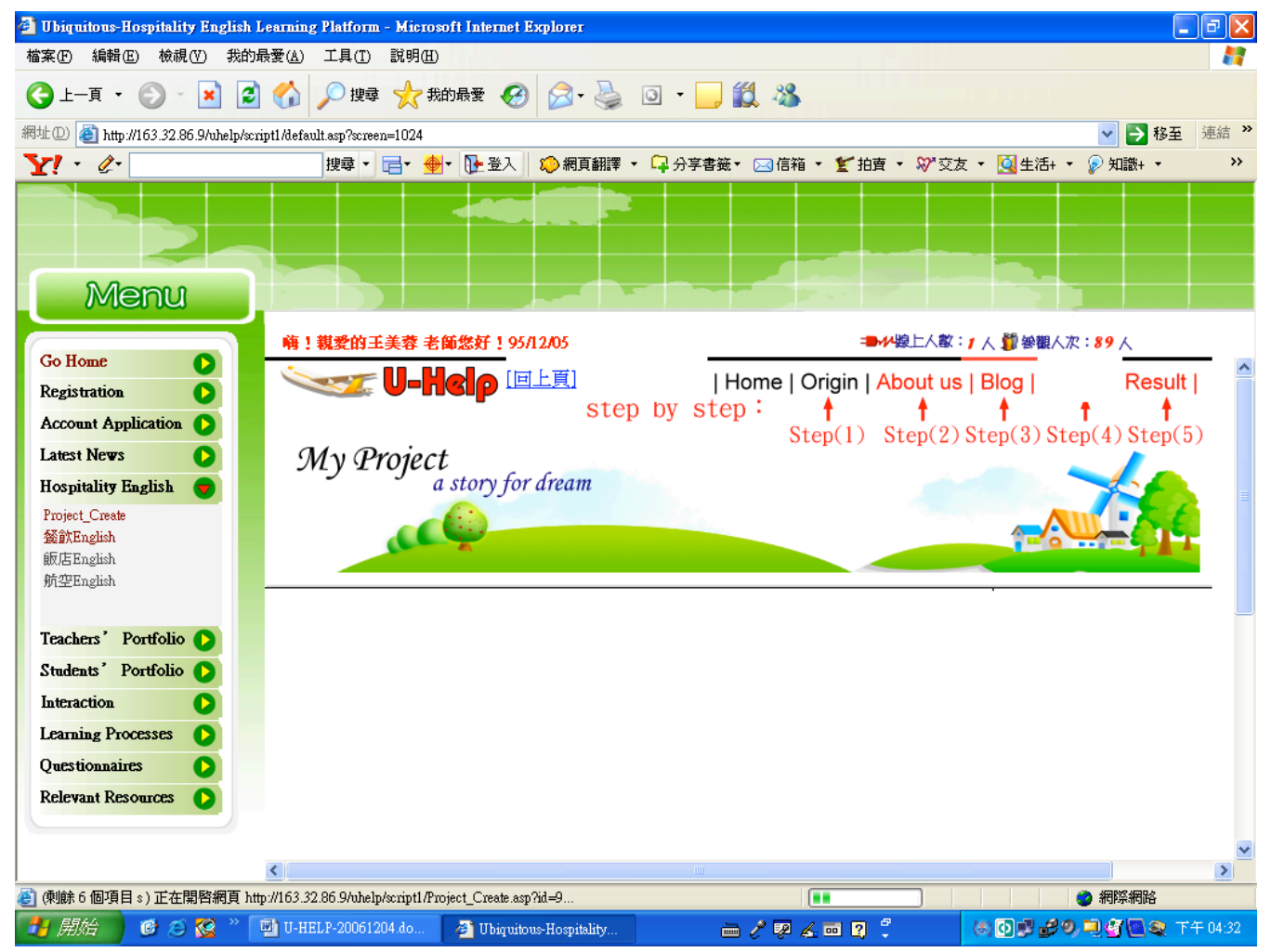

Figure 1: A welcome page of the area Project Conduction 


\section{The instructional platform}

The platform adopted in this study is the College's Ubiquitous Hospitality English Learning Platform (U-HELP) (Figure 1), which incorporates technology to enrich instructional variety and promote interaction among the students. The platform offers students many opportunities to practice hospitality English through the process oriented projects in which students must construct their own knowledge. There are mainly two learning activities included in the U-HELP. One is hospitality reading and the other is hospitality project conduction. For hospitality reading, the reading selections focus on hospitality culture in Taiwan. In addition, students may do follow up exercises such as vocabulary matching, true-false questions, and reading comprehension questions to check their understanding. Moreover, they are encouraged to share their reflections of the reading selections and discuss with other students in the discussion board.

For this study, the Project Conduction Area (PCA) in the U-HELP was adopted. To conduct the project, group members discussed the schedule in the project conduction area (Figure 2). Then, they uploaded their pictures and self introduction to the "About us" area (Figure 3). The area marked "Blog" was provided for group members to post their drafts and discuss them with each other (Figure 4). Finally, the subjects posted their final project in the area designated "Report." Sample pages of students' final projects are illustrated in Figure 5.

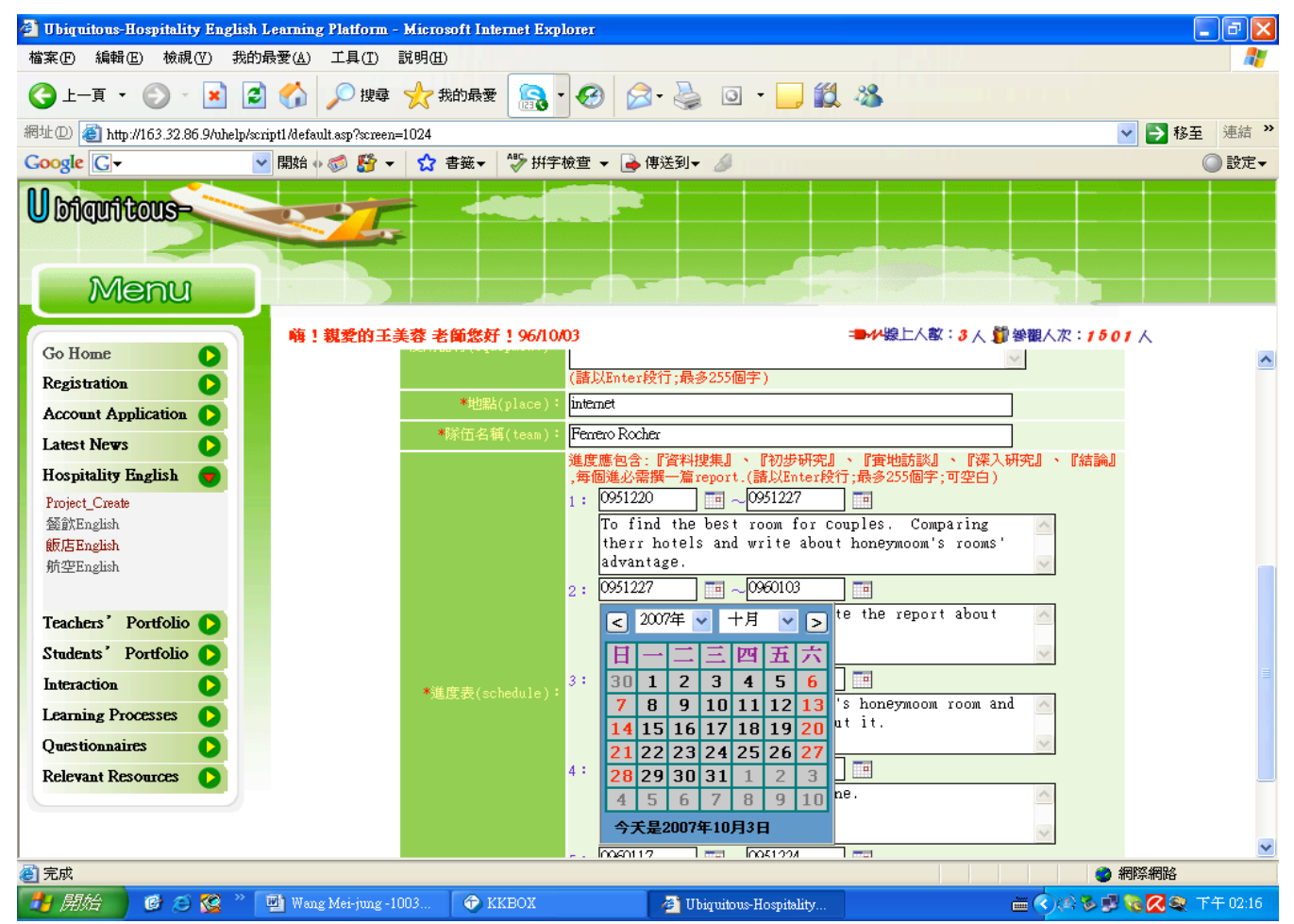

Figure 2: A sample page of Schedule Making 


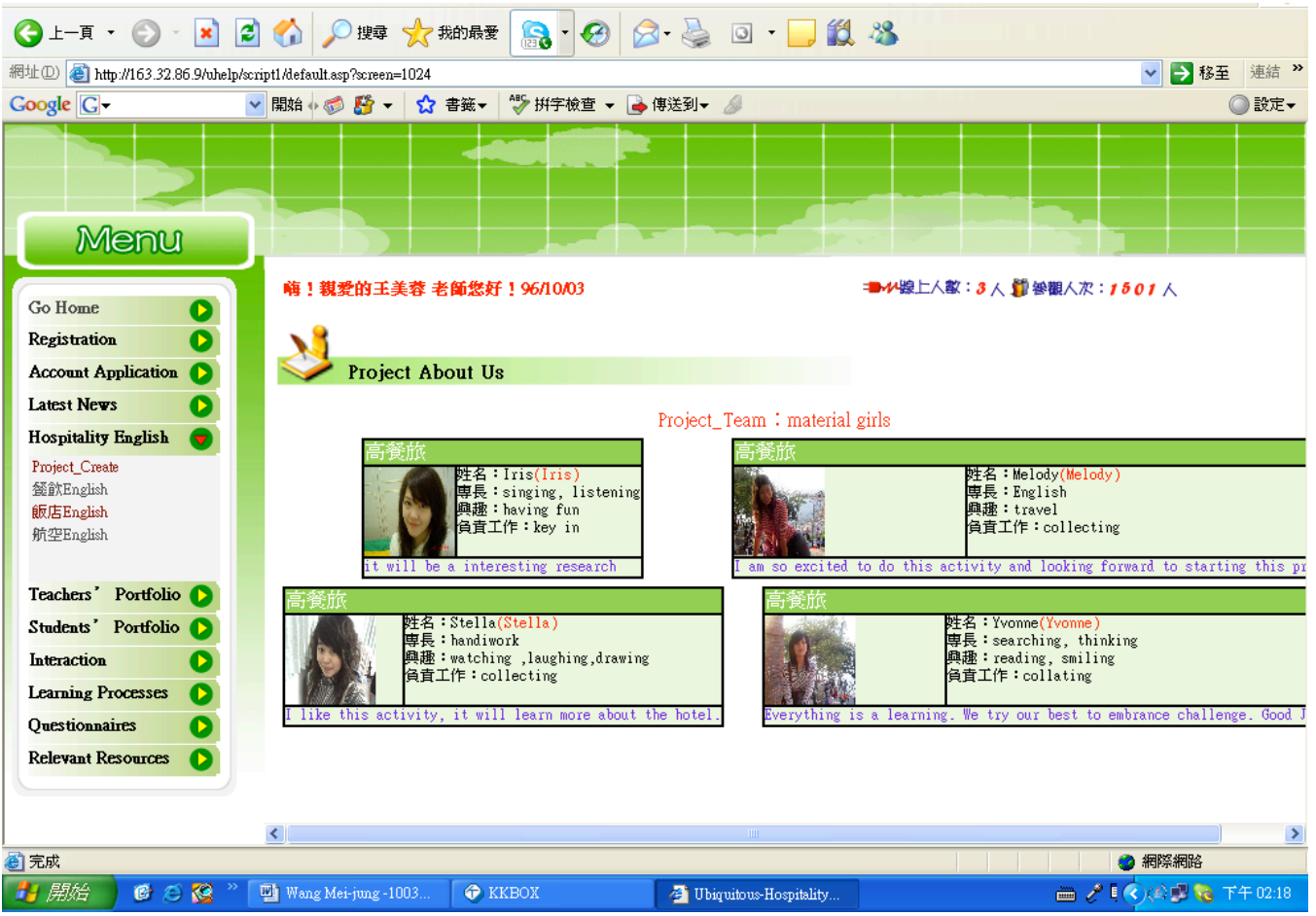

Figure 3: A sample page of About Us

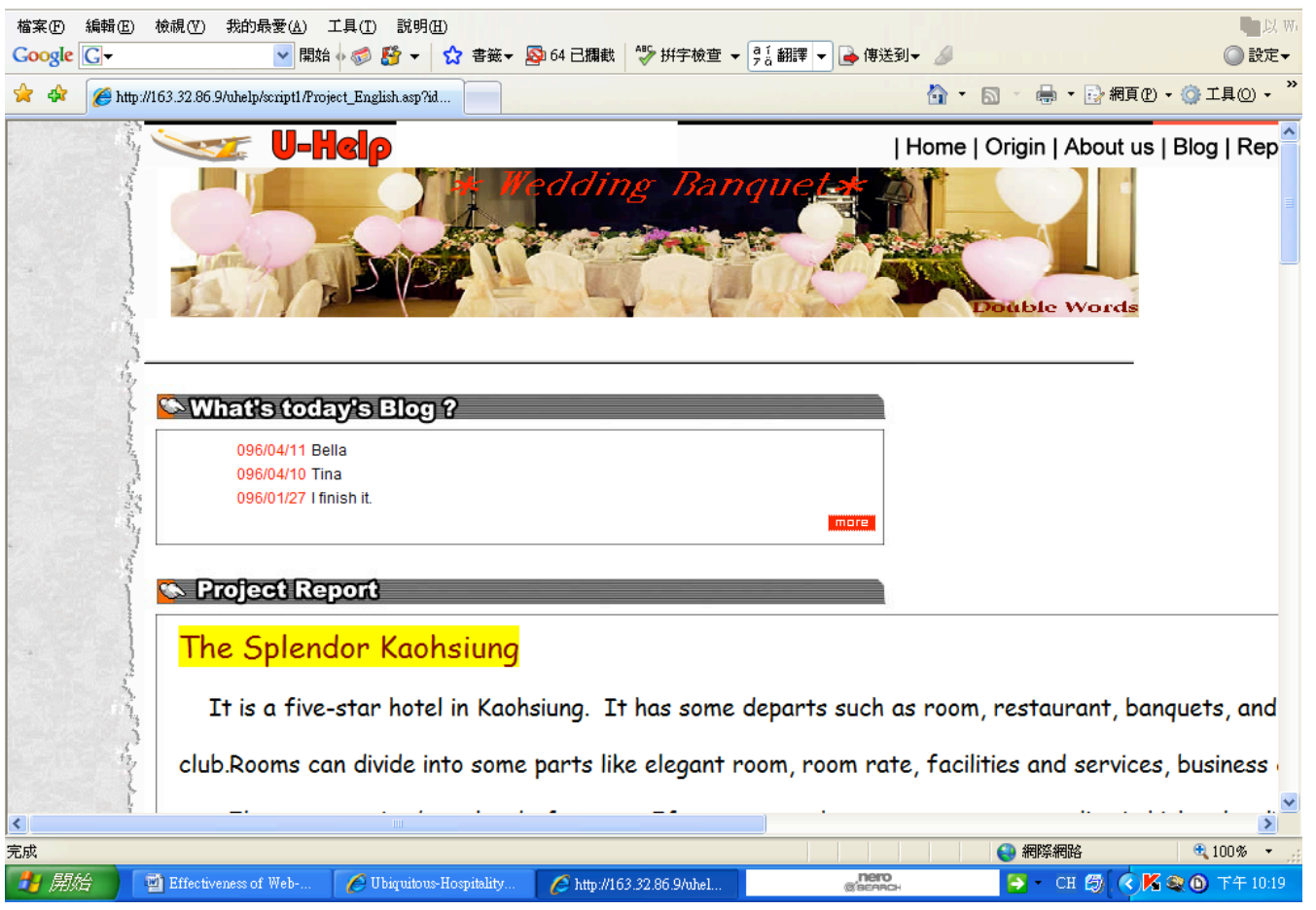

Figure 4: A sample page of students' blog 


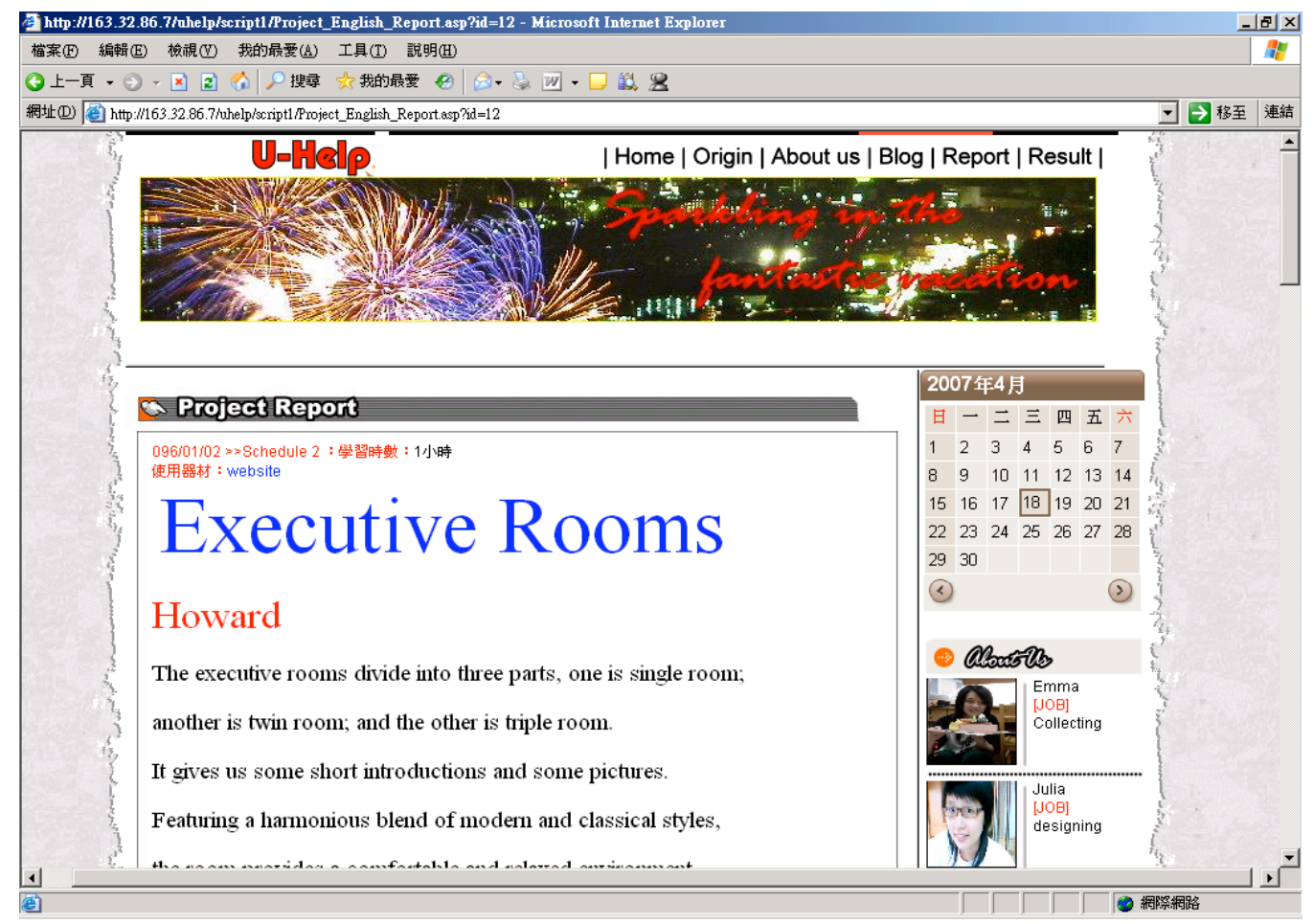

Figure 5: A sample page of students' final project

The instructional design of the U-HELP mainly follows the components of ADDIE (i.e., analysis, design, development, implementation and evaluation) and it is special in three aspects. First, it is tailor made for prospective staff in the hospitality industry. Most of the activities on the platform are task based and ESP oriented, which exposed students to situations they could relate to, and promoted language use by giving an opportunity to participate in tasks directly related to their future practice at work. Moreover, teachers and learners were provided with the necessary tools that foster language awareness and enable the students to discover for themselves the intricacies of language use with the aid of the program. Second, students were given the authorship to manage their own projects. On the platform, they learned to decide on learning tasks and establish the exploring processes and the procedures. At the end, their projects were published online. Through this process, students were empowered and engaged. Finally, the platform did not require students to have advanced computer competence. That is, they could concentrate on the information or content without worrying about how to make web pages or how to write programs. In this case, there was no intricacies in the user interface that might defeat students in the process of web based learning.

\section{Procedures}

The study lasted for six weeks. In the first week, guidelines for making the project were delivered and a one-hour orientation was provided to familiarise the subjects with the platform. Next, they conducted their projects. Each group had to search the English websites of the hotels. They chose three hotels (Each group chose 3 hotels, different from every other group.). Then each group focused on one topic, such as 
honeymoon rooms or banquet rooms, to compare the advantages and disadvantages of the chosen hotels. In their final product, they summarised the information they found on the websites and made a recommendation about which hotel they regarded as the best. All the web based projects were available for all students to read. Furthermore, the subjects were required to give feedback to other groups' projects by using the online discussion board. In their final reports, they reflected on the learning processes and provided feedback to the researcher. Both the project and the report were written in English. Finally, they answered the questionnaire designed for this study. The subjects' responses to the questionnaire and their final reports were analysed to answer the research questions.

\section{Data analyses}

Descriptive statistics were adopted to analyse the subjects' responses to the questionnaire. The subjects' final reports were qualitatively analysed. First, all the responses in the reports were read and reread. Reiterated themes were coded. During this process, several categories emerged. Those responses with the same theme were assigned to common categories. Afterwards, frequencies of each category were counted and discourse excerpts were selected to illustrate each category. The qualitative data provided clarification and depth to enrich the findings culled from the questionnaire. Although subjectivity is inevitable in interpreting the data, efforts have been made to keep objectivity for the data analyses.

\section{Results and discussion}

\section{Results of the questionnaire}

In this section, the results of the questionnaire are presented in two parts. The first part is focused on the learning task completed through the Project Conduction Area (PCA), whereas the second part is concerned with the effectiveness of the interface design of the PCA. Hereafter, the percentage of strongly agree and agree were added up to report the results. Table 1 shows that $62 \%$ of the subjects agreed that the learning tasks on the PCA helped them learn English more efficiently and 78\% of them expressed that they became familiar with hospitality culture. However, only $52 \%$ of the subjects agreed that the learning tasks promote their motivation to learn English. In terms of thinking abilities, $80 \%$ of the subjects agreed that the learning tasks on the PCA helped promote their thinking ability and $84 \%$ of the subjects agreed that it helped them understand different perspectives of thinking. With regard to interaction, $84 \%$ of the subjects the subjects agree that the learning tasks on the PCA increased the interaction among learners and $73 \%$ of the subjects believed that the tasks helped them learn English collaboratively.

The results show that a high percentage of the participants considered the learning tasks as helpful in the understanding of different perspectives of thinking, the increasing of interaction among the participants, and the enhancing of their critical thinking ability. However, the participants held a neutral attitude toward the effectiveness of the learning tasks on promoting English learning. The above findings were not surprising especially for students from Asian countries with Confucian heritage culture (CHC) (i.e. China, Vietnam, Singapore, Korea and Japan), who are used to the conventional knowledge transmission model, which places little emphasis on classroom participation and knowledge construction (Chen \& Looi, 2007; PhuongMai, Terlouw \& Pilot, 2005). 
Table 1: Students' responses to the learning task

\begin{tabular}{|c|c|c|c|c|c|c|}
\hline Items & $\mathrm{N}$ & SA & A & $\mathrm{N}$ & D & SD \\
\hline $\begin{array}{l}\text { The learning tasks on the PCA help me learn English } \\
\text { more efficiently. }\end{array}$ & 26 & $\begin{array}{c}0 \\
(0 \%)\end{array}$ & $\begin{array}{c}16 \\
(62 \%)\end{array}$ & $\begin{array}{c}5 \\
(19 \%)\end{array}$ & $\begin{array}{c}5 \\
(19 \%)\end{array}$ & $\begin{array}{c}0 \\
(0 \%)\end{array}$ \\
\hline $\begin{array}{l}\text { The learning tasks on the PCA let me be familiar } \\
\text { with hospitality culture in Taiwan. }\end{array}$ & 26 & $\begin{array}{c}3 \\
(11 \%)\end{array}$ & $\begin{array}{c}18 \\
(67 \%)\end{array}$ & $\begin{array}{c}1 \\
(4 \%)\end{array}$ & $\begin{array}{c}5 \\
(19 \%)\end{array}$ & $\begin{array}{c}0 \\
(0 \%)\end{array}$ \\
\hline $\begin{array}{l}\text { the PCA promote my } \\
\text { nglish. }\end{array}$ & 26 & $\begin{array}{c}0 \\
(0 \%)\end{array}$ & $\begin{array}{c}14 \\
(52 \%)\end{array}$ & $\begin{array}{c}7 \\
(26 \%)\end{array}$ & $\begin{array}{c}6 \\
(22 \%)\end{array}$ & $\begin{array}{c}0 \\
(0 \%)\end{array}$ \\
\hline $\begin{array}{l}\text { The learning tasks on the PCA enhance my critical } \\
\text { thinking ability. }\end{array}$ & 26 & $\begin{array}{c}0 \\
(0 \%)\end{array}$ & $\begin{array}{c}21 \\
(80 \%)\end{array}$ & $\begin{array}{c}3 \\
(11 \%)\end{array}$ & $\begin{array}{c}2 \\
(8 \%)\end{array}$ & $\begin{array}{c}0 \\
(0 \%)\end{array}$ \\
\hline $\begin{array}{l}\text { The learning tasks on the PCA help me understand } \\
\text { different perspectives of thinking. }\end{array}$ & 26 & $\begin{array}{c}1 \\
(4 \%)\end{array}$ & $\begin{array}{c}21 \\
(80 \%)\end{array}$ & $\begin{array}{c}4 \\
(15 \%)\end{array}$ & $\begin{array}{c}0 \\
(0 \%)\end{array}$ & $\begin{array}{c}0 \\
(0 \%)\end{array}$ \\
\hline $\begin{array}{l}\text { The learning tasks on the PCA help me to learn } \\
\text { English collaboratively. }\end{array}$ & 26 & $\begin{array}{c}3 \\
(11 \%)\end{array}$ & $\begin{array}{c}16 \\
(62 \%)\end{array}$ & $\begin{array}{c}4 \\
(15 \%)\end{array}$ & $\begin{array}{c}3 \\
(11 \%)\end{array}$ & $\begin{array}{c}0 \\
(0 \%)\end{array}$ \\
\hline $\begin{array}{l}\text { The learning tasks on the PCA incr } \\
\text { interaction with other learners. }\end{array}$ & 26 & $\begin{array}{c}1 \\
(4 \%)\end{array}$ & $\begin{array}{c}21 \\
(80 \%)\end{array}$ & $\begin{array}{c}2 \\
(8 \%)\end{array}$ & $\begin{array}{c}2 \\
(8 \%)\end{array}$ & $\begin{array}{c}0 \\
(0 \%)\end{array}$ \\
\hline
\end{tabular}

$\mathrm{SA}=$ Strongly agree; $\mathrm{A}=$ Agree; $\mathrm{N}=$ Neutral; $\mathrm{D}=$ Disagree; $\mathrm{SD}=$ Strongly disagree.

Students in this study were allowed to articulate their understanding and had their projects evaluated by both the teacher and peers. It could be inferred that the instructional design of the PCA increased interaction among students and thus enhanced students' higher order thinking abilities. However, students did not express a very high level of appreciation for the PCA in promoting their learning motivation and efficiency. The technology itself does not guarantee effective learning (Chen, 2005) and the radical change of instructional model might result in students' resistance in learning. It is of great importance for instructors to not only engage students in both content knowledge and language skills but also provide sufficient scaffolding to increase students' confidence in collaborative learning.

Table 2: Students' responses to the interface design of PCA

\begin{tabular}{|l|c|c|c|c|c|c|}
\hline \multicolumn{1}{|c|}{ Items } & $\mathrm{N}$ & $\mathrm{SA}$ & $\mathrm{A}$ & $\mathrm{N}$ & $\mathrm{D}$ & $\mathrm{SD}$ \\
\hline I think that the layout is simple and appropriate. & 26 & $\begin{array}{c}0 \\
(0 \%)\end{array}$ & $\begin{array}{c}17 \\
(65 \%)\end{array}$ & $\begin{array}{c}7 \\
(27 \%)\end{array}$ & $\begin{array}{c}2 \\
(8 \%)\end{array}$ & $\begin{array}{c}0 \\
(0 \%)\end{array}$ \\
\hline $\begin{array}{l}\text { I think that the color and background match each } \\
\text { other appropriately. }\end{array}$ & 26 & $\begin{array}{c}1 \\
(4 \%)\end{array}$ & $\begin{array}{c}15 \\
(58 \%)\end{array}$ & $\begin{array}{c}5 \\
(19 \%)\end{array}$ & $\begin{array}{c}5 \\
(19 \%)\end{array}$ & $\begin{array}{c}0 \\
(0 \%)\end{array}$ \\
\hline $\begin{array}{l}\text { I think that the information presented on each page } \\
\text { is appropriate. }\end{array}$ & 26 & 0 & 20 & 4 & 2 & 0 \\
$(0 \%)$ & $(76 \%)$ & $(16 \%)$ & $(8 \%)$ & $(0 \%)$ \\
\hline I think that operating procedures are clear. & 26 & $\begin{array}{c}1 \\
(4 \%)\end{array}$ & $\begin{array}{c}20 \\
(76 \%)\end{array}$ & $\begin{array}{c}2 \\
(8 \%)\end{array}$ & $\begin{array}{c}3 \\
(12 \%)\end{array}$ & $\begin{array}{c}0 \\
(0 \%)\end{array}$ \\
\hline $\begin{array}{l}\text { I think that the overall framework is complete so it } \\
\text { can be used easily. }\end{array}$ & 26 & $\begin{array}{c}0 \\
(0 \%)\end{array}$ & $\begin{array}{c}17 \\
(65 \%)\end{array}$ & $\begin{array}{c}8 \\
(31 \%)\end{array}$ & $\begin{array}{c}1 \\
(4 \%)\end{array}$ & $\begin{array}{c}0 \\
(0 \%)\end{array}$ \\
\hline I think that the linking between pages is efficient. & 26 & $\begin{array}{c}1 \\
(4 \%)\end{array}$ & $\begin{array}{c}21 \\
(80 \%)\end{array}$ & $\begin{array}{c}3 \\
(12 \%)\end{array}$ & $\begin{array}{c}1 \\
(4 \%)\end{array}$ & $\begin{array}{c}0 \\
(0 \%)\end{array}$ \\
\hline I think that it is easy to enter each function area. & 26 & $\begin{array}{c}1 \\
(4 \%)\end{array}$ & $\begin{array}{c}21 \\
(80 \%)\end{array}$ & $\begin{array}{c}3 \\
(12 \%)\end{array}$ & $\begin{array}{c}1 \\
(4 \%)\end{array}$ & $\begin{array}{c}0 \\
(0 \%)\end{array}$ \\
\hline
\end{tabular}

$\mathrm{SA}=$ Strongly agree; $\mathrm{A}=$ Agree; $\mathrm{N}=$ Neutral; $\mathrm{D}=$ Disagree; $\mathrm{SD}=$ Strongly disagree.

Table 2 shows the results of the second part of the questionnaire. The questionnaire shows that $65 \%$ of the subjects agreed that the layout was simple and appropriate. $62 \%$ of the subjects agreed that the color and background matched each other appropriately. $76 \%$ of the subjects agreed that the information presented on each page was appropriate. In addition, $65 \%$ of the subjects agreed that the overall framework was complete so it could be used easily. $80 \%$ of the subjects regarded the operating 
procedures as clear. $84 \%$ of the subjects agreed that the linking between pages was efficient and it was easy to enter each function area.

According to the results, the participants demonstrated more positive attitudes towards the operating process while they were more neutral to the aesthetic aspects of the interface design. The findings manifested that students seemed to be less satisfied with the visual design of the U-HELP. Although visual design is only a tool for relaying the message, it might influence the cognitive demands of psychological processes such as attention and perception or it might cause affective responses to the e-learning environment. Kanuka and Szabo (1999) stressed that instructional designers inevitably deal with visual design so that aesthetic principles, technical best practices, usability principles, and standards compliance constraints must be taken into consideration while designing e-learning screens to create an optimal online learning environment. More research could be conducted to reveal to what extent the visual design or the interaction of visual design and interaction design of the web pages impact the learning outcomes.

\section{Results from students' reports}

In this section, the subjects' final reports were analysed. The subjects' positive responses can be grouped into four main categories as presented in Table 3: (1) enhancing cooperation, (2) improving hospitality knowledge, (3) promoting thinking abilities, and (4) raising computer literacy. Each category is discussed in the following sections.

As revealed in most subjects' reports, one major advantage of this project is that students benefited from cooperation. In order to complete the project, they had to keep records of their progress, find information on the topic, collect data, and analyse the information they obtained. Then, they decided on a topic, solved their discrepancies in opinions, and reached a conclusion. In so doing, students were provided with more opportunities to engage in reflection and exploration of ideas. As a result, students in this study simultaneously learned language skills and valuable communication literacy. Furthermore, they were able to articulate their understanding and have their assignments evaluated by both the teacher and their peers.

The second advantage is the improvement of hospitality knowledge. The students know more about the hotels, including the services, facilities, and marketing. This is of essential importance for our students, since they are going to work in the hospitality industries after they graduate from college. The success of the project, to a certain degree, resulted from considering the three features common to English for specific purposes (ESP) courses: (a) authentic material, (b) purpose related orientation, and (c) self direction (Carter, 1983). The use of authentic learning materials is entirely feasible. The web based information adopted in this study is authentic content material. Purpose related orientation refers to the simulation of communicative tasks required of the target setting. The task in this study is to choose the best hotel for friends or family, which is a real life task. Finally, in order for self directed learning to occur, learners must have a certain degree of freedom to decide when, what, and how they will study.

The third category is the promotion of cognitive skills, including critical thinking and the development of different perspectives of thinking. As far as promoting varied perspectives of thinking is concerned, the students in this study had opportunities to view the assignments of other groups. This practice is not normal in traditional 
classrooms, because the only reader of student assignments is typically the teacher. Students seldom have the opportunity to learn from the homework of other students. By sharing one another's assignments, subjects became aware of other ways of thinking. When subjects interacted with one another, the sharing of ideas provided them with opportunities to refine and to reconstruct their internal thoughts. Their construction of knowledge hence begins in social experiences and ends with individual internalisation.

Table 3: Advantages of web based group projects

\begin{tabular}{|l|c|l|}
\hline \multicolumn{1}{|c|}{$\begin{array}{l}\text { Categories } \\
\text { cooperation }\end{array}$} & Frequency & \multicolumn{1}{c|}{ Samples } \\
\hline $\begin{array}{l}\text { Enhancing } \\
\text { 2. Improving } \\
\text { hospitality } \\
\text { knowledge }\end{array}$ & 17 & $\begin{array}{l}\text { Some can find some information, and some can categorise the } \\
\text { information, and the others can make the report better. In this way, } \\
\text { everyone can reveal their own specialty and have a perfect report. } \\
\text { (Student 10) } \\
\text { Group work is one of the good ways to learn how to cooperate with } \\
\text { people. It's good to have team members to work with. (Student 1) }\end{array}$ \\
\hline $\begin{array}{l}\text { Due to this project I knew hotels better, how they operate their } \\
\text { hotel, setting facilities and equipment, the advantages for guests, } \\
\text { how to offer the right service for guests, where to locate the right } \\
\text { position of each theme restaurant and also got a clear idea that the } \\
\text { Internet information of a hotel is very important. (Student 13) } \\
\text { Through this activity, I knew that what should be the trendiest } \\
\text { hotels like, what kinds of extra facilities they provide would attract } \\
\text { more travelers though they're for fun or for business. Moreover, a } \\
\text { good image depends on the design of hotel websites, if people } \\
\text { never go to the hotels. (Student 16) }\end{array}$ \\
\hline $\begin{array}{l}\text { 3. Promoting } \\
\text { cognitive } \\
\text { skills }\end{array}$ & 13 & $\begin{array}{l}\text { We can discuss together about the problem or to brainstorm some } \\
\text { better methods to introduce more about the hotel. When you have } \\
\text { different ideas, how do you stand your position or how to persuade } \\
\text { others? (Student 1) } \\
\text { I learned how to solve problems by myself and the importance of } \\
\text { working together. On the other hand, it helps me think efficiently } \\
\text { and add my ability of handling the problems. So, I like the kind of } \\
\text { project. (Student 19) }\end{array}$ \\
\hline $\begin{array}{l}\text { By doing the project, I also learned how to take good advantage of } \\
\text { the Internet and how to get more information from the Internet. } \\
\text { (Student 6) } \\
\text { literacy }\end{array}$ & 64 & $\begin{array}{l}\text { Besides, my English typing ability improves a lot. I could type even } \\
\text { faster and correctly than before. (Student 7) }\end{array}$ \\
\hline Totals & 10 & \\
\hline
\end{tabular}

Finally, the students improved their computer literacy. The mastery of technology, as part of the English curriculum and other curricula, is important with the popularity of the world wide web as an essential medium of information exchange in modern societies. There is an undeniable improvement of language skills and strategies related to handling information, and the language through which it is conveyed in the stages of searching, analysing, and processing information.

Despite the great deal of positive feedback generated by subjects toward the project, there are three categories of negative feedback identified from the subjects' final reports: (1) the time consuming nature of group work, (2) preference for traditional 
paper work, and (3) problems with using the PCA. The frequencies of the negative feedback are presented in Table 4.

Table 4: Negative feedback from the final reports

\begin{tabular}{|c|c|c|}
\hline Categories & Frequency & Samples \\
\hline \multirow[t]{2}{*}{$\begin{array}{l}\text { 1. The time } \\
\text { consuming } \\
\text { nature of } \\
\text { group work }\end{array}$} & 8 & $\begin{array}{l}\text { Sometimes it's good to work with people, and sometimes it isn't. } \\
\text { When people gather around, there are always many different ideas. } \\
\text { It's usually bad when everyone is insisted on which point of view. } \\
\text { Although giving ideas is good, people need to compromise between } \\
\text { each other. (Student } 4 \text { ). }\end{array}$ \\
\hline & & $\begin{array}{l}\text { I like individual homework. Because I don't have to worry we have } \\
\text { to arrange our time to get together to discuss the project. (Student } \\
\text { 15) }\end{array}$ \\
\hline \multirow[t]{2}{*}{$\begin{array}{l}\text { 2. Preference } \\
\text { for traditional } \\
\text { paper work }\end{array}$} & 6 & $\begin{array}{l}\text { I think that any chance to learn English is good, but I really don't } \\
\text { like to do it on line. I think internet is really convenience for doing } \\
\text { homework or submitting homework, but I feel tired after seeing the } \\
\text { screen for a long time. (Student 22) }\end{array}$ \\
\hline & & $\begin{array}{l}\text { I found there was a defect for UHEP after I finished my assignment. } \\
\text { Using UHELP you have to work in the Internet, but not every } \\
\text { student has a computer. If you work in a group, members use their } \\
\text { own computer and do their own assignment. The feeling of } \\
\text { working together may disappear. (Student 2) }\end{array}$ \\
\hline \multirow[t]{2}{*}{$\begin{array}{l}\text { 3. Problems } \\
\text { with using } \\
\text { the PCA }\end{array}$} & 5 & $\begin{array}{l}\text { The only thing that I think should be improved is the upload } \\
\text { system. When we uploaded our project and picture, the problem } \\
\text { came. We tried and tried, but didn't work. It really made us angry. It } \\
\text { took a lot of our time and energy. (Student 14) }\end{array}$ \\
\hline & & $\begin{array}{l}\text { During our work, my entire group members had to post on their } \\
\text { information more than twice, because this platform couldn't post on } \\
\text { very well. Such as, we want to change our picture at the first page; } \\
\text { we should key in our group name, topic...and so on when every } \\
\text { time we changed it. It was very troublesome that made us felt crazy. } \\
\text { (Student 24) }\end{array}$ \\
\hline Total & 18 & \\
\hline
\end{tabular}

The first category of negative feedback is the time consuming nature of group work, which resulted from two aspects. On one hand, it is difficult to deal with different viewpoints; on the other hand, it is time consuming to schedule and implement group discussion. In this study, the subjects had to devote a lot of time to sorting out divergences among group members. Unlike traditional learning, which is often dominated by teacher-talk where students have few opportunities to engage in meaningful talk that fosters critical thinking, this project includes the following components: an authentic context, multiple perspectives, and collaboration. Such practice, however, tends to be time consuming. Consequently, even though the subjects recognised that the process of sharing ideas provided the learners with opportunities to refine and reconstruct their internal thoughts, it is hard for them to cope with different opinions. As a result, they still prefer individual projects.

The second category is the preference for a traditional paper project. In this study, the subjects had to search the Internet and analyse the online information. Some of the subjects complained that this process caused eye fatigue. Some subjects expressed their preference for traditional paper work because it is easier for group work. These responses reflect the discussion in the previous section that the subjects in this study 
prefer face to face discussion. However powerful a new learning method is, learners may need time to adjust themselves to it and benefit from it.

The last negative feedback category is concerned with the problems of the PCA concerning the efficiency of the PCA. The problems typically occur when many users $\log$ onto the same website. Large delays caused stress, annoyance, and impatience, which made the users feel a lack of control over the tasks. In addition, the bandwidth should be sufficient and certain modifications of the PCA should be considered. The creation of a successful user interface design is typically an iterative process, with cycles of design, implementation, experimentation with users, and evaluation, followed by redesign and implementation of improvements, based on the results of user feedback (Alessi \& Trollip, 2001). If such changes are implemented, subjects will not encounter too much online congestion in a web based learning environment.

\section{Conclusions}

This study investigated students' perceptions of the acquisition of foreign language for specific purposes through an online project construction. The author examined students' responses to web based learning, their responses to the user interface design of the U-HELP, and their responses to the process of hospitality project construction. The findings showed that most of the subjects were positive towards web based learning and the interface design of the PCA. The learning tasks were considered as helpful in the understanding of different perspectives of thinking, the increasing of interaction among the subjects, and the enhancing of their critical thinking ability. However, the subjects held a more neutral attitude toward the effectiveness of the learning tasks on promoting English learning. In addition, more positive attitudes were demonstrated towards the operating process while they were more neutral to the other aspects of the interface design. Moreover, students' responses revealed that the web based projects have the following advantages: (1) enhancing cooperation, (2) improving hospitality knowledge, (3) promoting cognitive skills, and (4) raising computer literacy. However, negative comments were classified as followed: (1) the time consuming nature of group work, (2) preference for traditional paperwork, and (3) problems encountered in using the platform.

This study suggests that project based learning has the potential to bridge the gap between using English in class and using English in real life situations outside of class, as Stoller (1997) indicated. It provides learners with more authentic use of language. Also, thanks to the collaborative nature of project work, learners can learn to articulate their ideas, negotiate with others, and reflect on their own decisions. Moreover, with the integration of information technology into group project based learning, individuals' strengths and the cooperative learning in an online environment strengthen the work of the team. However, to reduce students' negative feedback as found in this study, both teachers and students must be well prepared in advance. For example, teachers could design the web based activity with clear guidelines to engage students in the process of project conduction. The guidelines could also familiarise students with the practices to which they may aim in web based learning. By so doing, students can appreciate the achievements that web based project construction, an alternative for face to face instruction, could bring for them.

There are several limitations of the study. First, the participants' improvement in language proficiency resulting from this activity was not measured by pre-and posttests. Their improvement in English was only identified by self perceptions of the 
students, not by carrying out pre- and post-tests. Second, the contents of their discussions were not analysed because the contents and process of their negotiation by media other than the blog provided in the PCA were not available. Finally, the effects of peer sharing in the process of project construction were not investigated. The above issues will be explored in the following studies on the U-HELP after the initial implementation. One study in 2008 investigated students' online interaction on the UHELP and offline interaction in the classroom to reveal the effectiveness of blending learning. In addition, another study conducted in 2009 explored the challenges encountered by two instructors who managed the online activities on the U-HELP for students from Taiwan and Macau.

The use of the Internet can implicitly give students simultaneous, natural, and typically incidental acquisition of computer literacy, which is necessary to handle hardware and software to fulfil tasks and to solve problems. No wonder many researchers (e.g. Virkus, 2003; Warschauer, 2002; George, McCausland, Wache \& Doskatsch, 2001) suggest that the electronic literacies of accessing and publishing web based information should become part of the curricula. Consequently, teachers might seriously consider reconstructing the curriculum of their English language courses in order to incorporate technology enhanced communication and project work. For future research, a long term study may be designed to examine how web based instruction and cooperative learning help language learners improve their language proficiency and communication skills. Furthermore, how students engage in peer tutoring and communicate electronically are also areas worth exploring.

\section{Acknowledgments}

This study was funded by the National Science Council in Taiwan under the contract number 96-2411-H-328-001. Special appreciation must be given to the students who participated in this study and the reviewers and the editor who provided precious comments. In addition, the author thanks the project assistant, Sandra Yang, for data collection and her colleagues, Mr Goodman and Mr Wolff, for proofreading the paper.

\section{References}

Blumenfield, P. C., Soloway, E., Marx, R. W., Krajcik, J. S., Guzdial, M. \& Palincsar, A. (1991). Motivating project-based learning: Sustaining the doing, supporting the learning. Educational Psychologist, 26, 369-98.

Carter, D. (1983). Some propositions about ESP. The ESP Journal, 2, 131-137.

Chang, Y. E. (2009). From nature of ESP research and practice to ESP teacher training. Paper presented in 2009 International Seminar on Applied Foreign Languages at National Kaohsiung Hospitality College, Kaohsiung.

Chen, C. F. (2005). Experience-based language learning through asynchronous discussion. Paper presented at the 22nd International Conference on English Teaching and Learning in the Republic of China, Taipei.

Chen, H. J. (2003). Developing a technology-enhanced self-access reading environment. Proceedings of 2003 International Conference on English teaching and learning in the Republic of China, Taipei, 103-116.

Chen, W. \& Looi, C.-K. (2007). Incorporating online discussion in face to face classroom learning: A new blended learning approach. Australasian Journal of Educational Technology, 23(3), 308327. http: / / www.ascilite.org.au/ajet/ajet23/chen.html 
Chun, D. M. \& Plass, J. L. (2000). Networked multimedia environments for second language learning. In Warschauer, M. \& Kern, S. (Eds.), Network-based language teaching: Concepts and practice. Cambridge: Cambridge University Press.

Coley, R.J., Cradler, J. \& Engel, P.K. (1997). Computers and classrooms: The status of technology in US schools. Princeton, NJ: Policy Education Center, Educational Testing Services.

Curtis, D. D. \& Lawson, M. J. (2001). Exploring collaborative online learning. Journal of Asynchronous Learning Networks, 5(1), 21-34. [verified 21 Oct 2009] http: / / www.aln.org/publications/jaln/v5n1/pdf/v5n1_curtis.pdf

Duch, B. (1996). Problem-based learning in physics: The power of students teaching students. Journal of College Science Teaching, 15(5), 326-329.

El-Hindi, E. (1998). Beyond classroom boundaries: Constructivist teaching with the Internet. The Reading Teacher, 51(8), 694-700.

Felix, U. (2002). The web as a vehicle for constructive approaches in language learning. ReCALL, $14(1), 2-15$

Foster, P. (1998). A classroom perspective on the negotiation of meaning. Applied Linguistics, 19, 123.

George, R., McCausland, H., Wache, D. \& Doskatsch, I. (2001). Information literacy: An institution-wide strategy. Australian Academic and Research Libraries, 32(4), 278-293. http: / / www.alia.org.au/publishing/ aarl/32.4/ full.text/george.html

Herrington, J. \& Standen, P. (2000). Moving from an instructivist to a constructivist multimedia learning environment. Journal of Educational Multimedia and Hypermedia, 9(3), 195-205.

Hoven, D. L. (2006). Communicating and interacting: An exploration of the changing roles of media in CALL/CMC. CALICO Journal, 23(2), 233-256. [verified 21 Oct 2009] http: / / auspace.athabascau.ca:8080/dspace/handle/2149/1678

Hse, C. Y. (2008). Hospitality management and education in China and Hong Kong. Paper presented in 2008 International Hospitality Education Conference, Kaohsiung.

Jonassen, D., Howland, J., Moore, J. \& Marra, R. (2003). Learning to solve problems with technology: A constructivist perspective (2nd Edition). New Jersey: Merrill Prentice Hall.

Kanuka, H. \& Szabo, M. (1999). Conducting research on visual design and learning: Pitfalls and promises. Canadian Journal of Educational Communication, 27(2), 39-57. [verified 21 Oct 2009, available from] http:/ / www.cjlt.ca/index.php/cjlt/issue/view/27

Lawrence, A. (1997.) Expanding capacity in ESOL programs (EXCAP): Using projects to enhance instruction. Literacy Harvest: The Journal of the Literacy Assistance Center, 6(1), 1-9.

Lin, N. T. (2006). The evolution of computer assisted language learning (CALL) and its teaching approaches. Proceedings of 2006 CHNA International Conference on Instruction and Learning, 105130.

Marcum, J. (2002). Rethinking information literacy. The Library Quarterly, 72(1), 1-26.

Maor, D. (2004). Pushing beyond the comfort zone: Bridging the gap between technology and pedagogy. In Beyond the comfort zone: Proceedings ASCILITE Perth 2004 (pp. 572-576). Perth, 5-8 December. http:/ / www.ascilite.org.au/ conferences/perth04/procs/maor.html

Meskill, C. \& Ranglova, K. (1999). Curriculum innovation in TEFL: A study of technologies supporting socio-collaborative language learning in Bulgaria. In M. Warschauer \& R. Kern, (Eds.), Network-based language teaching: Concepts and practice. Cambridge University Press.

Means, B. \& Olson, K. (1997). Technology and education reform. Office of Educational Research and Improvement, Contract No. RP91-172010. Washington, DC: US Department of Education. http:/ / www.ed.gov/pubs/SER/Technology/title.html [viewed 2 Feb 2003, verified 21 Oct 2009]. 
Miller, J., Deutsch, J. \& Sealey-Ruiz, Y. (2004). Advancing multicultural education in hospitality education through the use of food studies curricula. Journal of Hospitality and Tourism Education, 16(4), 45-51.

Moss, D. \& Van Duzer, C. (1998). Project-based learning and assessment: A resource manual for teachers. Arlington, VA: The Arlington Education and Employment Program (REEP). [verified 21 Oct 2009] http:/ / www.eric.ed.gov:80/ERICWebPortal/ contentdelivery/ servlet/ ERICServlet?accno=ED442306

Nunnally, J. C. \& Bernstein, I. H. (1994). Psychometric theory. 3rd ed. New York: McGraw-Hill.

Palincsar, A. (1991). Motivating project-based learning: Sustaining the doing, supporting the learning. Educational Psychologist, 26(3\&4), 369-398.

Phuong-Mai, N., Terlouw, C. \& Pilot, P. (2005). Cooperative learning vs Confucian heritage culture's collectivism: Confrontation to reveal some cultural conflicts and mismatch. Asia Europe Journal, 3(3), 403-419.

Shen, M. Y. (2006). A case study of EFL learner's language development in small group discussions: from a sciocultural perspective. Paper presented in the Second TELL conference, National Kaohsiung Normal University.

Stoller, F. L. (1997). Project work: A means to promote language content. Forum, 35(4). [viewed 22 Aug 2002, verified 21 Oct 2009]. http: / / eca.state.gov/forum/vols/vol35/no4/p2.htm

Takahashi, E. (1998). Language development in social interaction: A longitudinal study of a Japanese FLES program from a Vygotskyan approach. Foreign Language Annals, 31, 392-406.

Tsou, W. L. (2009). Developing NCKU's English for specific purposes program. Papers presented in the ESP workshop at National Kaohsiung Hospitality College.

Virkus, S. (2003). Information literacy in Europe: A literature review. Information Research, 8(4), paper no. 159. http: / / informationr.net/ir/8-4 / paper159.html [viewed 12 Mar 2007, verified 21 Oct 2009].

Warschauer, M. (2002). A developmental perspective on technology in language education. TESOL Quarterly, 36(3), 453-475.

Wrigley, H. S. (1998). Knowledge in action: The promise of project-based learning. Focus on Basics, 2(D), 13-18. [verified 21 Oct 2009] http:/ / www.ncsall.net/?id=384

Yi, H. (2001). Information literacy program: Achievements and improvements. Academic Exchange, 5(3), 199-204.

Dr Mei-jung Wang, Assistant Professor

Department of Applied English

National Kaohsiung Hospitality College

1, Sung-Ho Road, Hsiaokang District, Kaohsiung, Taiwan, 812

Email: sebrinajoy@yahoo.com.tw 